\title{
Determination of selected $\beta$-blockers and $\beta$-agonists in macrophytes plants used in constructed wetland
}

\author{
Daniel Wolecki ${ }^{1}$, Magda Caban ${ }^{1}$, Joanna Tabara' ${ }^{2}$, Piotr Stepnowski ${ }^{1}$, Jolanta Kumirska1 \\ ${ }^{1}$ Department of Environmental Analysis, Faculty of Chemistry, University of Gdańsk, Wita Stwosza 63, $80-308$ Gdańsk \\ ${ }^{2}$ Department of Water and Sewers Municipal Wastewater Treatment Plant, Sochaczew Ltd., Rozlazłowska 7, 96-500 Sochaczew \\ Corresponding author: daniel.wolecki@phdstud.ug.edu.pl \\ DOI: 10.31708/spi3.18/wolc.cns18
}

\section{Introduction}

The hydrophyte methods of water and wastewater treatment are based on the participation of both heterotrophic microorganisms as well as aquatic and hydrophilic plants (hydrophytes/macrophytes). The use of specific conditions in properly designed systems contributes to the intensification of oxidation and reduction processes which by assimilation, sedimentation and sorption processes, supported the removal of significant part of pollutants from wastewaters (ObarskaPempkowiak, Gajewska, \& Wojciechowska, 2010). According to literature data ( $\mathrm{Li}, \mathrm{Zhu}, \mathrm{Ng}$, \& Tan, 2014) constructed wetlands should hold great potential of being used as an alternative secondary wastewater treatment system or as a wastewater polishing treatment system for the removal of pharmaceuticals. Unfortunately, this general consensus is not well supported by relevant reported studies which are scarce and are not conclusive in their findings. In this study, we have checked the potential of three plant species planted on biological reactor in Wastewater Treatment Plant (WWTP) in Sochaczew to the removal of $\beta$-blocker and $\beta$-agonist residues from wastewater stream.

\section{Materials and Methods}

In this investigation $\beta$-blockers were represented by propranolol, pindolol, nadolol, whereas $\beta$-agonists by terbutaline. Three plant species: Umbrella papyrus, Lysimachia and Spindle were chosen as representatives of plans often used in constructed wetland and also applied in WWTP in Sochaczew. The target compounds were extracted from plant materials using Accelerated Solvent Extraction (ASE) technique, the purification of the obtained extracts was based on Solid Phase Extraction (SPE) using Oasis HLB sorbent (6 mL, $200 \mathrm{mg}$ ). Qualitative and quantitative analysis were carried out using gas chromatography coupled with mass spectrometry working in selected ion monitoring mode (GC-MS(SIM).

\section{Results}

Experimental data confirmed the presence of propranolol in Spindle and terbutaline in Lysimachia at concentration $2208.8 \mathrm{ng} / \mathrm{g}$ d.w. and $950.6 \mathrm{ng} / \mathrm{g}$ d.w., respectively. Only in Umbrella papyrus tissues target compounds were not identified.

\section{Discussion}

The obtained results confirmed that the removal of propanol from wastewaters is supported by Spindle species. Lysimachia could be used for intensification of the removal of terbutaline. Umbrella papyrus species does not support the removal of target drugs from wastewater stream.

\section{References}

Li, Y., Zhu, G., Ng, W. J., \& Tan, S. K. (2014). A review on removing pharmaceutical contaminants from wastewater by constructed wetlands: Design, performance and mechanism. Science of The Total Environment, 468-469, 908-932. https://doi.org/10.1016/j.scitotenv.2013.09.018

Obarska-Pempkowiak, H., Gajewska, M., \& Wojciechowska, E. (2010). Hydrofitowe oczyszczanie wód i ścieków. Wydawnictwo Naukowe PWN. Retrieved from https://mostwiedzy.pl/en/publication/hydrofitoweoczyszczanie-wod-i-sciekow, 114677-1 